\title{
Effect of Inorganic Fertilizers and Bio Fertilizers on Yield and Economics of Onion (Allium cepa L.) Production
}

\author{
Aditya Ranjan ${ }^{1 *}$, Kamal Kant ${ }^{2}$, Manish Kumar ${ }^{3}$, NehaKumariSingh ${ }^{4}$, \\ SumanKumari ${ }^{5}$ and Ritu Kumari ${ }^{6}$ \\ Department of Horticulture (Vegetable and Floriculture), BAC, Bihar Agricultural University, \\ Sabour, Bhagalpur-813210, India \\ *Corresponding author
}

A B S T R A C T

\begin{tabular}{l} 
Ke y w o r d s \\
Inorganic fertilizers, \\
Bio fertilizers, \\
Yield and \\
Economics, Onion \\
Article Info \\
$\begin{array}{l}\text { Accepted: } \\
\text { 05 February } 2020 \\
\text { Available Online: } \\
\text { 10 March 2020 }\end{array}$ \\
\hline
\end{tabular}

The experiment was carried out in the Department of Horticulture (Vegetable and Floriculture), Bihar Agricultural College, Sabour to study the role of bio fertilizers and chemical fertilizers on onion production. The experiment was laid out in a factorial randomized block design, replicated thrice with onion variety Agrifound Light Red. The experiment was framed with bio fertilizers viz., $\mathrm{M}_{0^{-}}$0, $\mathrm{M}_{1^{-}}$Azotobacter, $\mathrm{M}_{2}$-Azospirillum, $\mathrm{M}_{3^{-}}$ PSB, $\mathrm{M}_{4}$-VAM and four levels of chemical fertilizers, $\left(\mathrm{F}_{1}-\mathrm{N}_{80} \mathrm{P}_{40} \mathrm{~K}_{60}, \mathrm{~F}_{2^{-}}\right.$ $\mathrm{N}_{100} \mathrm{P}_{60} \mathrm{~K}_{80}, \quad \mathrm{~F}_{3}-\mathrm{N}_{120} \mathrm{P}_{80} \mathrm{~K}_{100}, \quad \mathrm{~F}_{4}-\mathrm{N}_{140} \mathrm{P}_{100} \mathrm{~K}_{120}$ having 20 treatment combinations. The results of the experiment showed that the fertility level $\mathrm{F}_{3}-\mathrm{N}_{120} \mathrm{P}_{80} \mathrm{~K}_{100}$ with inoculation of $\mathrm{M}_{2^{-}}$Azospirillum i.e., $\mathrm{F}_{3} \mathrm{M}_{2}$ the maximum average bulb weight $(77.53 \mathrm{~g})$, diameter of bulb $(6.17 \mathrm{~cm})$, bulb length $(5.97 \mathrm{~cm})$, bulb yield $(438.56 \mathrm{q} / \mathrm{ha})$ was recorded $\mathrm{F}_{3} \mathrm{M}_{2}$ treatment combination, and treatment combination $\mathrm{F}_{1} \mathrm{M}_{\mathrm{O}}$ shows lowest value. However, inoculation of Azospirillum with soil application at the fertility level of $\mathrm{F}_{3}-\mathrm{N}_{120} \mathrm{P}_{80} \mathrm{~K}_{100}$ was the most effective combination for higher net return and $\mathrm{B}: \mathrm{C}$ ratio (4.70).

\section{Introduction}

Onion (Allium cepa L.) is one of the important commercial vegetable crops grown in India. It belongs to family Amaryllidaceae, grown across over the country. India is $2^{\text {nd }}$ largest producer next to china. It is rich source of minerals like phosphorus, calcium and carbohydrate. It also contains protein, vitamin C. and it has good medicinal values, it act against carcinogenic factor. Low productivity of onion may be attributed due to poor management efficiency rather than that in the uncontrollable climatic factors. Thus, it 
makes it imperative to make a concerted effort to bridge the gap between potential yield and actual yield harvested by the farmers to make onion cultivation more remunerative through better management strategic of inputs like nutrient management practices and microbial inoculants for better exploitation of yield potentialities. Escalating cost of chemical fertilizers are hampering our way to produce more per unit area. Moreover, their excessive use has also resulted in serious damage to our soil and soil resources and to human health too. Biofertilizer are carrier based preparations containing beneficial microorganism in viable state for soil or seed application. In recent years they have emerged as a promising component of integrated nutrient supply system. They are likely to assume greater significance as a complements or supplements to the chemical fertilizers because of high nutrient turnover, exorbitant cost of fertilizers, soil and environmental protection. Biofertilizer are less expensive, ecofriendly viable and quality of produce, providing plant hormones and help in sustainable crop production through maintenance of soil productivity (Vijayakumar et al., 2000; Ramakrishnan and Thamizhiniyan, 2004). The use of chemical fertilizers in combination with bio fertilizers offers a great opportunity to increase the crop production at less cost (Gunjan et al., 2005). Therefore, the experiment was conducted for sustainable production of onion with combine use of bio fertilizers and chemical fertilizers.

\section{Materials and Methods}

The investigation was carried out at Vegetable research farm, BAU, Sabour in the Rabi season 2018. The design of experiment was factorial randomized block design, replicated thrice and variety was "Agrifound Light red". 45 days old seedlings of uniform growth were transplanted in evening hour at a spacing of $15 \times 10 \mathrm{~cm}$ in flat beds. The plot size was $2.5 \mathrm{~m} \times 1.5 \mathrm{~m}$. The treatment comprised four bio fertilizers (Mo-No biofertilizer, $\quad \mathrm{M}_{1}$-Azotobacter, $\quad \mathrm{M}_{2}$ Azospirillum, $\mathrm{M}_{3}$-PSB, $\mathrm{M}_{4}-\mathrm{VAM}$ ) and four levels of chemical fertilizers $\left(\mathrm{F}_{1}-\mathrm{N}_{80} \mathrm{P}_{40} \mathrm{~K}_{60}\right.$, $\mathrm{F}_{2}-\mathrm{N}_{100} \mathrm{P}_{60} \mathrm{~K}_{80}, \quad \mathrm{~F}_{3}-\mathrm{N}_{120} \mathrm{P}_{80} \mathrm{~K}_{100}, \quad \mathrm{~F}_{4}-$ $\mathrm{N}_{140} \mathrm{P}_{100} \mathrm{~K}_{120}$ ). Bio fertilizers were used as soil application. Treatment wise different microbial inoculants were applied at the rate of $5 \mathrm{~kg} / \mathrm{ha}$ and dried F.Y.M in the ratio of 1:20 were mixed thoroughly and mixture was broadcasted and incorporated in the sub-plots. After application of the microbial inoculants the seedlings allocated with respective microbial inoculants were transplanted at the spacing of $15 \times 10 \mathrm{~cm}$. Full dose of phosphorus $\left(\mathrm{P}_{2} \mathrm{O}_{5}\right)$ as diammonium phosphate and potash $\left(\mathrm{K}_{2} \mathrm{O}\right)$ as murate of potash with $1 / 3$ rd dose of nitrogen as urea were applied before transplanting of seedlings as basal dressing commensurating with treatments specifications. As per treatment the remaining dose of $\mathrm{N}$ was top dressed in two equal split i.e., one third at 25 days of transplanting and the rest at 50 days after transplanting. Necessary irrigations were given. Gap filling, intercultural operation and plant protection measures were given for the better establishment of crop.

The observations of growth parameter plant height, number of leaves per plant, diameter of leaves, and yield attributing characters like bulb length, bulb diameter, bulb weight and bulb yield. The statistical analysis of the data noted in all observations was carried out by the method of "Analysis of variance as suggested by Fisher and Yates (1963). Comparison of the treatments was made with the help of critical differences (C.D.). The economics studies of the crop was done by computing the cost of cultivation and net profit in rupees per hectare on the basis of the prevailing rate of inputs and output obtained from the local market. Gross return was calculated by multiplying yield (q/ha) with 
average selling rate of onion bulbs. The net return (Rs/ha) was computed by subtracting the cost of cultivation from the gross return obtained from the sale of the harvested bulb. The benefit cost ratio i.e. the net return per rupee investment was obtained by dividing net profit with total cost of cultivation.

\section{Results and Discussion}

The results revealed that the application of microbial inoculant $\mathrm{M}_{2}$ (Azospirillum) produced maximum plant height $(48.57 \mathrm{~cm})$, number of leaves per plant (11.54), leaf length $(43.66 \mathrm{~cm})$, diameter of leaves $(1.87 \mathrm{~cm})$ This treatment was most outstanding being significantly superior to rest of the biofertilizers used.

This may be due to change in the metabolic activities of the plant and the uptake of water and nutrients. In addition to these, microbial inoculants have ability to produce some growth promoting substances which might have led to enhanced cell division and cell elongation, resulting maximum plant length and highest number of leaves per plant, leaf length, collar thickness and fresh weight of leaves/ plant. The results in respect of these characters are in complete agreement with the findings of Mahmoud and El-Hefny (1999), Rather et al., (2003) and Jha et al., (2006). It is evident from the data this treatment was also found effective for producing maximum bulb length $(5.59 \mathrm{~cm})$, bulb diameter $(6.11 \mathrm{~cm})$, bulb weight $(77.14 \mathrm{~g})$, bulb yield $(435.72 \mathrm{q} / \mathrm{ha})$ followed by the application of $\mathrm{M}_{1}$ i.e., Azotobacter. The yield improvement might be due to vigorous habit in terms of plant height, leaf length, number of leaves and plants developed under Azospirillum or Azotobacter.

Azospirillum might have fixed higher amount of nitrogen in soil and made available to the plants resulting in better uptake of $\mathrm{N}$ by plants. VAM or PSB would have caused more mobilization and solubilization of insoluble $\mathrm{P}$ in the soil and improve the availability of phosphorus to plants. Better crop due to all these factors which might have helped in increasing photosynthetic rate and more physiological and biochemical activities which in turn, perhaps increased the movement of photosynthates from source to sink. Thus, finally resulted in increasing the yield and yield components. These results are in accordance with the findings of Muthuramalingam et al., (2002), Sule et al., (2002), Rather et al., (2003), Yadav et al., (2005) and Jha et al., (2006).

Growth and yield attributing characters were influenced significantly due to different fertility level. The maximum plant height $(44.90 \mathrm{~cm})$, number of leaves per plant (10.39), leaf length $(39.86 \mathrm{~cm})$, bulb length $(5.31 \mathrm{~cm})$, bulb diameter $(5.46 \mathrm{~cm})$, bulb weight $(70.37 \mathrm{~g})$, bulb yield (392.94 q/ha), and were obtained at the fertility level F3$\mathrm{N}_{120} \mathrm{P}_{80} \mathrm{~K}_{100}$, This level was most outstanding being significantly superior to rest of the fertility Significant increase in bulb yield due to different fertility levels has been reported by Girigowda et al., (2005), Kumar et al., (2006) and Dilruba et al., (2006).

The interaction effect between different levels of inorganic fertilizers and bio fertilizers were found to be quite superior to their sole application. Among the treatment combinations $\mathrm{F}_{3} \mathrm{M}_{2}$ i.e., application of higher dosages of inorganic fertilizers i.e., $F_{3}$ $\left(\mathrm{N}_{120} \mathrm{P}_{80} \mathrm{~K}_{100}\right)$ along with inoculation of biofertilizer $\mathrm{M}_{2}$ (Azospirillum) exhibited significantly highest values of plant height $(48.57 \mathrm{~cm})$, number of leaves per plant(11.54), leaf length $(43.66 \mathrm{~cm}), \quad$ bulb length $(5.97 \mathrm{~cm})$, bulb diameter $(6.17 \mathrm{~cm})$, bulb weight $(77.53 \mathrm{~g})$, bulb yield (438.56q/ha). 
Table.1 Effect of levels of biofertilizer and chemical fertilizer on growth and yield attributes for sustainable onion production

\begin{tabular}{|c|c|c|c|c|c|c|c|}
\hline Treatments & $\begin{array}{c}\text { Plant } \\
\text { height } \\
(\mathrm{cm} .)\end{array}$ & $\begin{array}{l}\text { No.of } \\
\text { leaves } \\
\text { /Plant }\end{array}$ & $\begin{array}{c}\text { Leaf } \\
\text { length } \\
\text { (cm.) }\end{array}$ & $\begin{array}{c}\text { Bulb } \\
\text { length } \\
\text { (cm) }\end{array}$ & $\begin{array}{c}\text { Bulb } \\
\text { diameter } \\
(\mathrm{cm})\end{array}$ & $\begin{array}{c}\text { Bulb } \\
\text { weight } \\
\text { (g) }\end{array}$ & $\begin{array}{l}\text { Bulb } \\
\text { yield } \\
\text { q/ha }\end{array}$ \\
\hline \multicolumn{8}{|c|}{ Level of Bio fertilizers } \\
\hline $\mathrm{M}_{0}$-No biofertilizer & 31.74 & 7.46 & 27.89 & 3.77 & 4.20 & 49.31 & 278.43 \\
\hline $\mathbf{M}_{1}$ Azotobacter & 46.94 & 10.85 & 41.35 & 5.32 & 5.83 & 75.46 & 420.00 \\
\hline $\mathrm{M}_{2}$ Azospirillum & 47.13 & 11.04 & 41.64 & 5.59 & 6.11 & 77.14 & 435.72 \\
\hline $\mathbf{M}_{3}$ PSB & 44.96 & 10.45 & 40.64 & 5.41 & 5.47 & 72.24 & 393.83 \\
\hline $\mathbf{M}_{4} \mathbf{V A M}$ & 39.94 & 9.38 & 35.48 & 4.80 & 4.82 & 62.80 & 343.70 \\
\hline CD at $5 \%$ & 1.99 & 0.50 & 1.95 & 0.24 & 0.24 & 3.71 & 20.06 \\
\hline \multicolumn{8}{|c|}{ Level of chemical fertilizer } \\
\hline$F_{1}-N_{80} P_{40} K_{60}$ & 40.48 & 9.04 & 34.46 & 4.36 & 4.96 & 63.02 & 350.69 \\
\hline $\mathbf{F}_{2}-\mathbf{N}_{100} \mathbf{P}_{60} K_{80}$ & 44.48 & 10.23 & 39.24 & 5.19 & 5.38 & 69.63 & 384.77 \\
\hline $\mathbf{F}_{3^{-}}-\mathbf{N}_{120} \mathbf{P}_{80} K_{100}$ & 44.90 & 10.39 & 39.86 & 5.31 & 5.46 & 70.37 & 392.94 \\
\hline $\mathbf{F}_{4}-\mathbf{N}_{140} P_{100} K_{120}$ & 42.70 & 9.69 & 36.05 & 5.07 & 5.33 & 66.54 & 368.94 \\
\hline CD at $5 \%$ & 1.78 & 0.44 & 1.74 & 0.22 & 0.22 & 3.32 & 17.94 \\
\hline
\end{tabular}

Table.2 Combined effect of bio fertilizers and chemical fertilizer on growth and yield attributes for onion production

\begin{tabular}{|l|c|c|c|c|c|c|c|}
\hline Interaction & $\begin{array}{c}\text { Plant } \\
\text { height } \\
\text { (cm.) }\end{array}$ & $\begin{array}{c}\text { No. of } \\
\text { leaves } \\
\text { /Plant }\end{array}$ & $\begin{array}{c}\text { Leaf } \\
\text { length } \\
\mathbf{( c m} \text { ) }\end{array}$ & $\begin{array}{c}\text { Bulb } \\
\text { length } \\
\mathbf{( c m})\end{array}$ & $\begin{array}{c}\text { Bulb } \\
\text { diameter } \\
(\mathbf{c m})\end{array}$ & $\begin{array}{c}\text { Bulb } \\
\text { weight } \\
(\mathbf{g})\end{array}$ & $\begin{array}{c}\text { Bulb yield } \\
(\mathbf{q} / \mathbf{h a})\end{array}$ \\
\hline $\mathbf{F}_{\mathbf{1}} \mathbf{M}_{\mathbf{0}}$ & 24.50 & 5.86 & 21.20 & 2.88 & 3.25 & 37.64 & 211.45 \\
\hline $\mathbf{F}_{\mathbf{1}} \mathbf{M}_{\mathbf{1}}$ & 46.99 & 11.11 & 42.53 & 5.51 & 5.66 & 74.21 & 409.13 \\
\hline $\mathbf{F}_{\mathbf{1}} \mathbf{M}_{\mathbf{2}}$ & 49.51 & 11.35 & 43.25 & 5.67 & 6.03 & 76.66 & 433.22 \\
\hline $\mathbf{F}_{\mathbf{1}} \mathbf{M}_{\mathbf{3}}$ & 45.22 & 10.31 & 39.78 & 5.31 & 5.11 & 70.46 & 388.21 \\
\hline $\mathbf{F}_{\mathbf{1}} \mathbf{M}_{\mathbf{4}}$ & 36.20 & 8.66 & 31.89 & 4.41 & 4.70 & 56.13 & 311.46 \\
\hline $\mathbf{F}_{\mathbf{2}} \mathbf{M}_{\mathbf{0}}$ & 34.56 & 7.99 & 30.57 & 4.11 & 4.51 & 54.32 & 306.21 \\
\hline $\mathbf{F}_{\mathbf{2}} \mathbf{M}_{\mathbf{1}}$ & 49.07 & 11.21 & 42.78 & 5.57 & 5.82 & 75.91 & 423.66 \\
\hline $\mathbf{F}_{\mathbf{2}} \mathbf{M}_{\mathbf{2}}$ & 49.53 & 11.52 & 43.43 & 5.92 & 6.11 & 77.51 & 435.99 \\
\hline $\mathbf{F}_{\mathbf{2}} \mathbf{M}_{\mathbf{3}}$ & 46.40 & 10.52 & 41.20 & 5.43 & 5.61 & 73.21 & 396.75 \\
\hline $\mathbf{F}_{\mathbf{2}} \mathbf{M}_{\mathbf{4}}$ & 42.85 & 9.99 & 38.23 & 4.92 & 4.87 & 67.21 & 361.24 \\
\hline $\mathbf{F}_{\mathbf{3}} \mathbf{M}_{\mathbf{0}}$ & 35.30 & 8.33 & 31.12 & 4.20 & 4.66 & 55.01 & 311.26 \\
\hline $\mathbf{F}_{\mathbf{3}} \mathbf{M}_{\mathbf{1}}$ & 49.49 & 11.35 & 43.15 & 5.63 & 5.98 & 76.25 & 430.22 \\
\hline $\mathbf{F}_{\mathbf{3}} \mathbf{M}_{\mathbf{2}}$ & 49.57 & 11.56 & 43.66 & 5.97 & 6.17 & 77.53 & 438.56 \\
\hline $\mathbf{F}_{\mathbf{3}} \mathbf{M}_{\mathbf{3}}$ & 46.55 & 10.56 & 42.14 & 5.48 & 5.63 & 73.43 & 401.12 \\
\hline $\mathbf{F}_{\mathbf{3}} \mathbf{M}_{\mathbf{4}}$ & 43.60 & 10.24 & 39.25 & 5.25 & 4.87 & 69.65 & 383.54 \\
\hline $\mathbf{F}_{\mathbf{4}} \mathbf{M}_{\mathbf{0}}$ & 32.60 & 7.70 & 28.66 & 3.88 & 4.37 & 50.26 & 284.78 \\
\hline $\mathbf{F}_{\mathbf{4}} \mathbf{M}_{\mathbf{1}}$ & 48.65 & 11.20 & 42.74 & 5.57 & 5.82 & 75.47 & 416.99 \\
\hline $\mathbf{F}_{\mathbf{4}} \mathbf{M}_{\mathbf{2}}$ & 49.53 & 11.45 & 43.42 & 5.83 & 6.11 & 76.87 & 435.11 \\
\hline $\mathbf{F}_{\mathbf{4}} \mathbf{M}_{\mathbf{3}}$ & 45.60 & 10.51 & 40.62 & 5.42 & 5.52 & 71.87 & 389.25 \\
\hline $\mathbf{F}_{\mathbf{4}} \mathbf{M}_{\mathbf{4}}$ & 37.12 & 8.71 & 32.53 & 4.63 & 4.82 & 58.21 & 318.56 \\
\hline & & & & & & & \\
\hline
\end{tabular}


Table.3 Effect of levels of biofertilizer and chemical fertilizer on economics for sustainable onion production

\begin{tabular}{|l|c|c|c|c|c|c|}
\hline Treatment & $\begin{array}{c}\text { Bulb yield } \\
\text { (q/ha) }\end{array}$ & $\begin{array}{c}\text { Rate in } \\
(\mathbf{q} / \mathbf{h a})\end{array}$ & $\begin{array}{c}\text { Gross income } \\
\mathbf{( R s )}\end{array}$ & $\begin{array}{c}\text { Total cost of } \\
\text { cultivation } \mathbf{( R s )}\end{array}$ & $\begin{array}{c}\text { Net income } \\
\text { (Rs) }\end{array}$ & $\begin{array}{c}\text { B : } \mathbf{C} \\
\text { Ratio }\end{array}$ \\
\hline $\mathbf{F}_{\mathbf{1}} \mathbf{M}_{\mathbf{0}}$ & 271.45 & 1000 & 271450 & 71931 & 199519 & $\mathbf{2 . 7 7}$ \\
\hline $\mathbf{F}_{\mathbf{1}} \mathbf{M}_{\mathbf{1}}$ & 409.13 & 1000 & 409130 & 75931 & 333199 & 4.39 \\
\hline $\mathbf{F}_{\mathbf{1}} \mathbf{M}_{\mathbf{2}}$ & 403.22 & 1000 & 403220 & 75931 & 327289 & 4.31 \\
\hline $\mathbf{F}_{\mathbf{1}} \mathbf{M}_{\mathbf{3}}$ & 388.21 & 1000 & 388210 & 75931 & 312279 & 4.11 \\
\hline $\mathbf{F}_{\mathbf{1}} \mathbf{M}_{\mathbf{4}}$ & 361.46 & 1000 & 361460 & 75931 & 285529 & 3.76 \\
\hline $\mathbf{F}_{\mathbf{2}} \mathbf{M}_{\mathbf{0}}$ & 326.21 & 1000 & 326210 & 77251 & 248959 & 3.22 \\
\hline $\mathbf{F}_{\mathbf{2}} \mathbf{M}_{\mathbf{1}}$ & 413.66 & 1000 & 413660 & 81251 & 332409 & 4.09 \\
\hline $\mathbf{F}_{\mathbf{2}} \mathbf{M}_{\mathbf{2}}$ & 420.99 & 1000 & 420990 & 81251 & 339739 & 4.18 \\
\hline $\mathbf{F}_{\mathbf{2}} \mathbf{M}_{\mathbf{3}}$ & 396.75 & 1000 & 396750 & 81251 & 315499 & 3.88 \\
\hline $\mathbf{F}_{\mathbf{2}} \mathbf{M}_{\mathbf{4}}$ & 361.24 & 1000 & 361240 & 81251 & 279989 & 3.45 \\
\hline $\mathbf{F}_{\mathbf{3}} \mathbf{M}_{\mathbf{0}}$ & 311.26 & 1000 & 311260 & 72952 & 238308 & 3.27 \\
\hline $\mathbf{F}_{\mathbf{3}} \mathbf{M}_{\mathbf{1}}$ & 425.22 & 1000 & 425220 & 76952 & 348268 & 4.53 \\
\hline $\mathbf{F}_{\mathbf{3}} \mathbf{M}_{\mathbf{2}}$ & 438.56 & 1000 & 438560 & 76952 & 361608 & $\mathbf{4 . 7 0}$ \\
\hline $\mathbf{F}_{\mathbf{3}} \mathbf{M}_{\mathbf{3}}$ & 401.12 & 1000 & 401120 & 76952 & 324168 & 4.21 \\
\hline $\mathbf{F}_{\mathbf{3}} \mathbf{M}_{\mathbf{4}}$ & 395.54 & 1000 & 395540 & 76952 & 318588 & 4.14 \\
\hline $\mathbf{F}_{\mathbf{4}} \mathbf{M}_{\mathbf{0}}$ & 334.78 & 1000 & 334780 & 73491 & 261289 & 3.56 \\
\hline $\mathbf{F}_{\mathbf{4}} \mathbf{M}_{\mathbf{1}}$ & 416.99 & 1000 & 416990 & 77491 & 339499 & 4.38 \\
\hline $\mathbf{F}_{\mathbf{4}} \mathbf{M}_{\mathbf{2}}$ & 415.11 & 1000 & 415110 & 77491 & 337619 & 4.36 \\
\hline $\mathbf{F}_{\mathbf{4}} \mathbf{M}_{\mathbf{3}}$ & 389.25 & 1000 & 389250 & 77491 & 311759 & 4.02 \\
\hline $\mathbf{F}_{\mathbf{4}} \mathbf{M}_{\mathbf{4}}$ & 308.56 & 1000 & 308560 & 77491 & 231069 & 2.98 \\
\hline & & & & & \\
\hline
\end{tabular}

This may be due to the profuse vegetative growth induced by higher dose of chemical fertilizers and application of microbial inoculant $\mathrm{M}_{2}$ (Azospirillum). This ultimately may increase the photosynthetic assimilation. All these physiological activities brought about increase in bulb size and bulb weight as the weight of individual bulb increased it reflected positively on the total bulb yield. The results are closely in consonance with the finding of Singh and Singh (2002), El-Shaikh (2005), Jayathilake et al., (2002), Singh and Pandey (2006) and Yogita and Ram (2012)

\section{Economics}

The interaction between bio fertilizers and inorganic fertilizers was found to be highly significant, meaning thereby that different fertility levels influenced the bio fertilizers behavior and vice-versa. The highest net profit of Rs.361608.00/ha with the maximum benefit-cost ratio of 4.70 were obtained with the application of microbial inoculant $\mathrm{M}_{2}$ (Azospirillum) at the fertility level of $\mathrm{F}_{3}$ $\left(\mathrm{N}_{120} \mathrm{P}_{80} \mathrm{~K}_{100}\right)$ i.e., $\mathrm{F}_{3} \mathrm{M}_{2}$. The lowest fertility level of $F_{1}$ in the absence of bio fertilizers i.e., $\mathrm{F}_{1} \mathrm{M}_{\mathrm{O}}$ produced the minimum net profit (Rs. 199519. 00/ha) with $\mathrm{B}$ : C ratio (2:77).

Application of higher dosages of inorganic fertilizers i.e. $\mathrm{F}_{3}\left(\mathrm{~N}_{120} \mathrm{P}_{80} \mathrm{~K}_{100}\right)$ along with inoculation of bio fertilizer $\mathrm{M}_{2}$ (Azospirillum) influenced the growth as well as yield 
contributing characters and bulb yield significantly in comparison to the remaining treatment combinations. Hence, the use and management of natural resources in sustainable agriculture, the microbial fertilizers hold vast potential for the future.

\section{References}

Dilruba, S., Alam, M.M., Rahman M.A., and Hasan M. F. 2006. Influence of nitrogen and potassium on yield contributing bulb traits of onion. International J. Agril. Res. 1 (1): 85-90.

El- Shaikh and K.A.A., 2005. Growth and yield of onion as affected by biofertilization, application of nitrogen and phosphorus fertilizers under South Valley Conditions. Assiut J. Agril. Sci. 36 (1): 37-50.

Fisher, R.A., and Yates, F. 1963. Statistical tables for Biological, Agricultural and Medical Research, Long Man Group Limited, London. Sixth Edition.

Girigowda, J.R., Narasegowda, N. C. and Krishna, H. C. 2005. Effect of fertilizer levels on uptake of primary nutrients and bulb yield of on hybrids. Mysore J. Agril. Sci. 39 (4): 557-560.

GunjanAswani, Paliwal, R. and Saralia, D. K. 2005. Effect of nitrogen and biofertilizers on yield and quality of rabi onion (Allium cepa L.) cv. Puna Red. Agril. Sci. Digest, 25 (2): 124-126.

Jayathilake, P.K.S., Reddy, I. P., Srihari, D., Neeraja, G. and Reddy, R. 2002. Effect of nutrient management on growth, yield and yield attributes of rabionion (Allium cepa L.). Vegetable Science. 29(2): 184-
185.

Jha, A.K., Pal, Netra, Saxena, A.K., Singh, Dhyan and Jha, G. K. 2006. Coinoculation effect of VAM and PGR on growth and yield of onion. Ind. J. Hort. 63 (1): 44-47.

Kumar Susheel, Tiwari Sushant, C. P. and Singh, Vijay 2006. Bulb yield and quality of onion (Allium cepa L.) as affected by application rates of nitrogen and potassium fertilizer. Agril. Sci. Digest. 26 (1): 11-14.

Singh, A., Singh, S. P. and Singh, B. O. 2002. Effect of VAM and inorganic fertilizers on growth and yield of onion (Allium cepa L.). Vegetable Science. 29 (1): 4042.

Sule, S.R., Rahane, R. K. and Shinde, V. A. 2002. Impact of biofertilizers on productivity of field crops. $J$. Maharashtra Agril. Univ. 27 (2): 180181.

Vijayakumar, B.S., P. V.Bhiravamurthy and Anand, M. C. 2000. VAM fungi association in Lycoperiscon esculentum L. grown in semi-arid tropical soils of Puttaparthy, A.P.J. Ecobiol., 12 (1): 7374.

YadavDashrath, Prasad, V. M. and Gujar, K. D. 2005. Effect of different biofertilizers in association with phosphorus on growth and yield of onion (Allium cepa L.), a white onion var. JNDWO. New Agriculturist. 16 (1/2): 87-89.

Yogita and Ram, R. B. 2012. Interaction effect of chemical and bio-fertilizers on growth and yield of onion (Allium cepa L.). Hort Flora Research Spectrum, 1(3): 239-243.

\section{How to cite this article:}

Aditya Ranjan, Kamal Kant, Manish Kumar, Neha Kumari Singh, Suman Kumari and Ritu Kumari. 2020. Effect of Inorganic Fertilizers and Bio Fertilizers on Yield and Economics of Onion (Allium cepa L.) Production. Int.J.Curr.Microbiol.App.Sci. 9(03): 603-608. doi: https://doi.org/10.20546/ijcmas.2020.903.071 